\title{
Cloning and Characterization of Overlapping DNA Fragments of the Toxin A Gene of Clostridium difficile
}

\author{
By CHRISTOPH VON EICHEL-STREIBER, * DETLEV SUCKAU, \\ MANFRED WACHTER AND ULRICH HADDING \\ Institut für Medizinische Mikrobiologie, Johannes-Gutenberg-Universität, Hochhaus am \\ Augustusplatz, 6500 Mainz, FRG
}

(Received 25 March 1988; revised 29 July 1988; accepted 29 September 1988)

\begin{abstract}
Clostridium difficile, a human pathogen, produces two very large protein toxins, A and B (250$600 \mathrm{kDa}$ ), which resist dissociation into subunits. To clone the toxin A gene, a genomic library of 3-8 kb chromosomal DNA fragments of $C$. difficile strain VPI 10463 established in pUC12 was screened with a rabbit polyclonal toxin $A$ antiserum. Thirty-five clones were isolated which carried $2.5-7.0 \mathrm{~kb}$ inserts representing a $10 \mathrm{~kb}$ region of the $C$. difficile genome. All the inserts were oriented in the same direction, suggesting that toxin A gene expression was under control of the lac promoter of the $\mathrm{pUC1} 2$ vector. Western blot experiments revealed the presence of low amounts of fusion proteins of variable size (30-170 kDa) in Escherichia coli strains harbouring recombinant plasmids. As deduced from subcloning experiments, the DNA sequences encoding toxin A comprised about $4 \mathrm{~kb}$, corresponding to about $140 \mathrm{kDa}$ of the $300-600 \mathrm{kDa}$ protein. This was either due to incomplete cloning of the gene or it might indicate a subunit composition of toxin A. No additional gene(s) with homology to the cloned toxin A gene was detected.
\end{abstract}

\section{INTRODUCTION}

Many Clostridium species produce toxins as factors of pathogenicity. For some of the most prominent representatives, like Clostridium tetani, Clostridium botulinum and Clostridium perfringens, intensive studies have been undertaken to characterize the toxins at the protein level (Middlebrook \& Dorland, 1984). Toxinogenic Clostridium difficile strains are correlated with a pseudomembranous colitis (PMC) (Bartlett et al., 1978). The development of this disease, which may even be lethal, is a severe side effect of treatment of patients with various antimicrobial agents (George, 1986). The disease is correlated with the presence of toxins whose role in the progress of the PMC is not yet exactly defined. Two very large toxins, A and B (Sullivan et al., 1982 ) or $D_{1}$ and $D_{2}$ (Banno et al., 1984), have been described, with molecular masses of 300$600 \mathrm{kDa}(\mathrm{A})$, and $250-500 \mathrm{kDa}(\mathrm{B})$ and, additionally, two low-molecular-mass proteins also called A and B (52 kDa toxin A, Rihn et al., 1984; $150 \mathrm{kDa}$ toxin B, Pothoulakis et al., 1986). The amino acid composition of the high-molecular-mass toxins is similar (Lyerly et al., 1986 b). Their dissociation into subunits by mercaptoethanol treatment has not been achieved. At present the molecular masses of toxins A and B are not precisely known. Despite their mercaptoethanol resistance, the possibility still remains that they comprise a number of subunits, as was deduced from the reactivity of toxin A with monoclonal antibodies (Lyerly $e t$ al., 1986a).

Immunological characterization of the two toxins has led to conflicting results. Polyclonal antibodies raised against $A$ and $B$ react specifically with the toxin used for immunization and neutralize specifically the activity of the homologous toxin (Laughon et al., 1984). However, some monoclonal antibodies (mAbs) cross-react with both toxins regardless of the toxin used for

Abbreviation: mAb, monoclonal antibody. 
immunization (v. Eichel-Streiber et al., 1987; Lyerly et al., 1986a). These results are further complicated by the finding that polyclonal Clostridium sordellii antitoxin neutralizes the activity of both toxin A and toxin B (Chang et al., 1986).

The activities of the two toxins in vivo and in vitro appear to differ. When added to cultures of $\mathrm{CHO}$ cells, toxin B is about 1000 -fold more active than toxin A. Injected intraperitoneally, both toxins have about the same toxicity (Sullivan et al., 1982; v. Eichel-Streiber et al., 1987). After gastric application, only toxin A exerts a toxic effect (Lyerly et al., 1985a). These results, taken together with the reactivity of toxin A and B towards mAbs (Lyerly et al., $1985 b$; Lyerly et al., 1986a), have led us to postulate that toxin A may represent a precursor form which is processed to toxin B after transport and specific interaction with a target cell (v. Eichel-Streiber et al., 1987).

Recombinant DNA techniques have previously been used to show homologies at the genetic level between toxins isolated from different bacteria (Timmis et al., 1984). However, little is known about the genetics of these highly toxic clostridial toxins. The tetanus toxin gene has been cloned and sequenced (Eisel et al., 1986; Fairweather et al., 1986). The cloning of a $0.3 \mathrm{~kb}$ fragment of the $C$. difficile toxin A gene has also been reported recently (Muldrow et al., 1987). We here present the cloning and molecular characterization of a $10 \mathrm{~kb}$ region encoding part, at least, of toxin A. In addition, we have tested whether a single gene encodes both toxins A and B.

\section{METHODS}

Strains, enzymes, and chemicals. The toxinogenic $C$. difficile strain VPI 10463 was kindly supplied by N. Sullivan (Sullivan et al., 1982) and grown in brain/heart infusion broth (Bio Merieux, France) at $39^{\circ} \mathrm{C}$ under anaerobic conditions without shaking. For cloning experiments Escherichia coli was grown in LB medium (Maniatis et al., 1982), with vigorous shaking at $37^{\circ} \mathrm{C}$ for JM83 and JM101 (Yanisch-Perron et al., 1985), and at $30^{\circ} \mathrm{C}$ for pop2136 - this strain carries the cI857(Ts) repressor (Haymerle et al., 1986). Enzymes were supplied by Boehringer and BRL, chemicals by Sigma and Merck.

Antibody production. Two-month-old New Zealand White rabbits were immunized intramuscularly with FPLCpurified toxin A (v. Eichel-Streiber $e t$ al., 1987). For the first injection a 1:1 mixture of $200 \mu$ protein $(10 \mu \mathrm{g})$ and $200 \mu \mathrm{l}$ complete Freund's adjuvant was used. Further booster injections were given at 10-14 d intervals using toxin and incomplete Freund's adjuvant $(200 \mu \mathrm{l}$ each). The first challenge was carried out with $10 \mu \mathrm{g}$ toxin, and five additional injections with $20 \mu \mathrm{g}$ of toxin. Serum was taken and analysed by ELISA and immunoblotting as previously described (v. Eichel-Streiber et al., 1987).

Isolation of DNA, restriction analysis and cloning. $C$. difficile was grown to the early exponential phase to isolate chromosomal DNA. The DNA was prepared using methods described by Miura (1967). Partial digestion of the prepared DNA, and restriction analysis and subsequent cloning of sized DNA, were done by established procedures (Maniatis et al., 1982). DNA minipreparations were done according to the procedure of Volkaert (1987).

The expression vectors pEX1, 2 and 3 were used for subcloning experiments (Stanley \& Luzio, 1984). These vectors allow fragments to be cloned in all three reading frames. Expression is under the control of the cI857(Ts) repressor (chromosomally encoded by the recipient $E$. coli strain pop2136) and may be induced by shifting the growth temperature in the early exponential phase from $30^{\circ} \mathrm{C}$ to $42{ }^{\circ} \mathrm{C}$.

Construction of a genomic library. Recombinant DNA techniques were used according to the guidelines of the Bundesministerium für Forschung und Technologie, FRG. C. difficile DNA (fragments larger than $50 \mathrm{~kb}$ ) was digested with a mixture of $A l u I$ and $H a e I I I$ into fragments of $1-20 \mathrm{~kb}$ in length. Fragments in the size range 3-8 kb $(2.0 \mu \mathrm{g}$ sample), isolated from agarose gels (Maniatis et al., 1982), were ligated to $0.25 \mu \mathrm{g}$ SmaI-digested and dephosphorylated pUC12 (Messing, 1979). The recombinant DNA was introduced into $E$. coli JM83 by transformation (Hanahan, 1983). Cells were plated out on $24 \times 24 \mathrm{~cm}$ plates. On six plates 70000 independent clones were obtained. They were resuspended in LB containing ampicillin $\left(100 \mu \mathrm{g} \mathrm{ml}^{-1}\right)$, supplemented with $10 \%$ $(\mathrm{v} / \mathrm{v})$ glycerol, divided into $50 \mu \mathrm{l}$ portions and frozen at $-70^{\circ} \mathrm{C}$. An $800 \mu \mathrm{l}$ volume of a 1:10000 dilution of the frozen stock solution was plated to achieve a cell density of 12000 on a $24 \times 24 \mathrm{~cm}$ plate.

Isolation of toxin-A-positive clones. The 70000 colonies plated out on six $24 \times 24 \mathrm{~cm}$ plates (see above) were screened using a procedure described by Stanley \& Luzio (1984). For colony blotting, rabbit toxin A antiserum was used at a dilution of 1:2000. Anti rabbit-peroxidase conjugate (Dako) was taken at a dilution of 1:1000. Staining was done with diaminobenzidine $\left(0.5 \mathrm{mg} \mathrm{m}^{-1}\right)$ as substrate in the presence of hydrogen peroxide $\left(0.06 \mu \mathrm{g} \mathrm{ml}^{-1}\right)$. Positive clones were isolated as single colonies and retested for toxin expression. Recombinant clones were also tested for toxin activity in the CHO test as described prevously (v. Eichel-Streiber et al., 1987).

Subcloning of $p C d$ insert $D N A$. A $1.9 \mathrm{~kb}$ PstI fragment was isolated from pCd14. It extends from the $P_{s t} \mathrm{I}$ site at 
$2.6 \mathrm{~kb}$ to the PstI site in the polylinker at the right side of the insert DNA (see Fig. 2). This fragment was cloned into Pst I-digested and dephosphorylated pEX1, 2 and 3 in both orientations.

Hybridization experiments. These were done by standard procedures (Southern, 1975; Reed \& Mann, 1985). In order to detect toxin-A-related genes within the genome of $C$. difficile VPI 10463, $4 \mu \mathrm{g}$ chromosomal DNA was digested for $3 \mathrm{~h}$ with 40 units of the appropriate restriction enzymes and hybridized with pCd10 or pCd14 insert DNA. Radioactive DNA probes were labelled with $\left[\alpha^{-32}\right.$ P $]$ dATP (Amersham) by nick translation (Rigby $e t a l$., 1977). After hybridization, washing was carried out at various stringencies equivalent to between $13^{\circ} \mathrm{C}$ and $47^{\circ} \mathrm{C}$ below the melting point $\left(T_{\mathrm{m}}\right)$ of the DNA $\left(T_{\mathrm{m}}: 84^{\circ} \mathrm{C}\right.$, measured in $5 \times \mathrm{SSC}$ solution). The conditions equivalent to $13^{\circ} \mathrm{C}$ below $T_{\mathrm{m}}$ were $57^{\circ} \mathrm{C}, 50 \%(\mathrm{v} / \mathrm{v})$ formamide, $0.1 \times \mathrm{SSC}$; those equivalent to $47^{\circ} \mathrm{C}$ below $T_{\mathrm{m}}$ were $23{ }^{\circ} \mathrm{C}, 0 \%$ formamide, $0.1 \times$ SSC (Howley et al., 1979). $(1 \times \mathrm{SSC}$ is $0.15 \mathrm{M}-\mathrm{NaCl}, 0.015 \mathrm{M}$-trisodium citrate, $\mathrm{pH} 7.0)$.

Recombinant protein. A fresh $5 \mathrm{ml} \mathrm{LB}+$ ampicillin culture was inoculated with $50 \mu \mathrm{l}$ of recombinant clones grown overnight. After 3-4 h, cells were harvested by centrifugation, and resuspended in $250 \mu$ l sodium phosphate buffer ( $25 \mathrm{mM}, \mathrm{pH} 7.5$ ) and $250 \mu \mathrm{l}$ SDS-PAGE dye solution without 2-mercaptoethanol (Laemmli, 1970). After 10 min incubation at $95^{\circ} \mathrm{C}$ the lysed cell suspension was sonicated for 5-10 s to reduce the viscosity. The pEX subclones were grown to early exponential phase at $30^{\circ} \mathrm{C}$ and then shifted to $42^{\circ} \mathrm{C}$ by adding an equal volume of growth medium heated to $54^{\circ} \mathrm{C}$. After this induction, cells were grown for a further $1 \mathrm{~h}$. Total cell lysates were prepared as described above. Gel electrophoresis and Western blotting were done as previously described (v. Eichel-Streiber et al., 1987). Three antibodies were used sequentially for staining: toxin A antiserum (1:2000 dilution), goat anti-rabbit serum (1:1000 dilution; Dianova), and rabbit anti-goat-peroxidase conjugate $(1: 1000$ dilution; Dako). In all three antibody incubations $E$. coli absorption protein was included $(1: 10 \mathrm{v} / \mathrm{v})$ to reduce the background generated by $E$. coli-specific antibodies present in almost every polyclonal serum. Absorption protein was prepared from a 5 litre culture of $E$. coli JM83 in the late exponential phase. Cells were harvested, resuspended to $1 \%$ of their original volume in Tris/ $\mathrm{HCl}(25 \mathrm{mM}, \mathrm{pH} 8.0)$ plus sucrose $(12.5 \% \mathrm{w} / \mathrm{v})$ and digested with lysozyme $\left(25 \mathrm{ng} \mathrm{ml}^{-1}\right)$ for $40 \mathrm{~min}$. Triton X-100 $(0.1 \%)$ was added to give $3 \%$ of the original volume, then the lysate was heated to $65^{\circ} \mathrm{C}$ for $10 \mathrm{~min}$, centrifuged for $30 \mathrm{~min}$ at 25000 r.p.m. (Beckman, $45 \mathrm{Ti}$ rotor) and the supernatant used as absorption protein.

In Western blot experiments with mAbs, a 1:1000 dilution of the chosen antibodies [mAbs 1339, 1134 and 1337; rabbit anti-mouse-peroxidase conjugate (Dako)] was used. For screening of the genetic library, a mixture of four mAbs was used (mAbs 1339, 1322, 1142 and 1134; v. Eichel-Streiber et al., 1987). The isolated recombinant proteins were stained with a 1:2 dilution of cell supernatant of hybridoma cell line 1337 .

\section{RESULTS AND DISCUSSION}

\section{Construction of a genomic library of $C$. difficile and screening with toxin A antiserum}

In order to clone the toxin A gene, a genomic library of randomly cut chromosomal DNA of $C$. difficile VPI 10463 was initially established. Toxins A and B of VPI 10463 have been reported to have molecular masses between 150 and $500 \mathrm{kDa}$ (depending on the experimental conditions). Genes encoding proteins of this size would occupy 7-16 kb of DNA. To avoid the expression of the complete, functional toxin A (600 kDa on native PAGE gels, $300 \mathrm{kDa}$ on SDS-PAGE for $C$. difficile strain VPI 10463) and thus follow the safety guidelines, an overlapping set of fragments smaller than $8 \mathrm{~kb}$ was cloned. Partial digestion with Sau $3 \mathrm{~A}$ could not be used successfully to generate a continuous smear of fragmented DNA on agarose gels. However, using AluI and HaeIII together, fragments of different size ranges could be produced depending on the conditions used.

DNA cut with $A l u \mathrm{I} / \mathrm{HaeIII}$ was separated on an agarose gel and fragments of 3-8 kb were isolated and ligated with the SmaI-cut and dephosphorylated vector pUC12 (Messing, 1979). In pUC12, a representative library of 70000 independent clones was obtained, $95 \%$ of which contained inserts, as judged by DNA minipreparations. The library was complete, as deduced from the number of clones obtained, and stable according to subsequent experiments with isolated clones. In contrast, $C$. difficile DNA has been reported to be unstable in some other vectors like $\lambda \mathrm{gt} 11$ (Muldrow et al., 1987). All of the clones so far analysed carried inserts of less than $7.0 \mathrm{~kb}$, with an average size of $5 \mathrm{~kb}$.

The rabbit antiserum used for screening of the library specifically reacted with toxin A (Fig. 1) and was effective at dilutions of 1:72000 and 1:10000 in ELISA and immunoblot experiments, respectively. Fig. 1 also shows the cross-reaction of the mAbs 1339 and 1134 with toxin A and B (lanes 5-8). Screening of the library with the rabbit antiserum yielded 35 independent clones. BamHI digestion of the plasmid DNA isolated from these clones showed that the sizes of the 


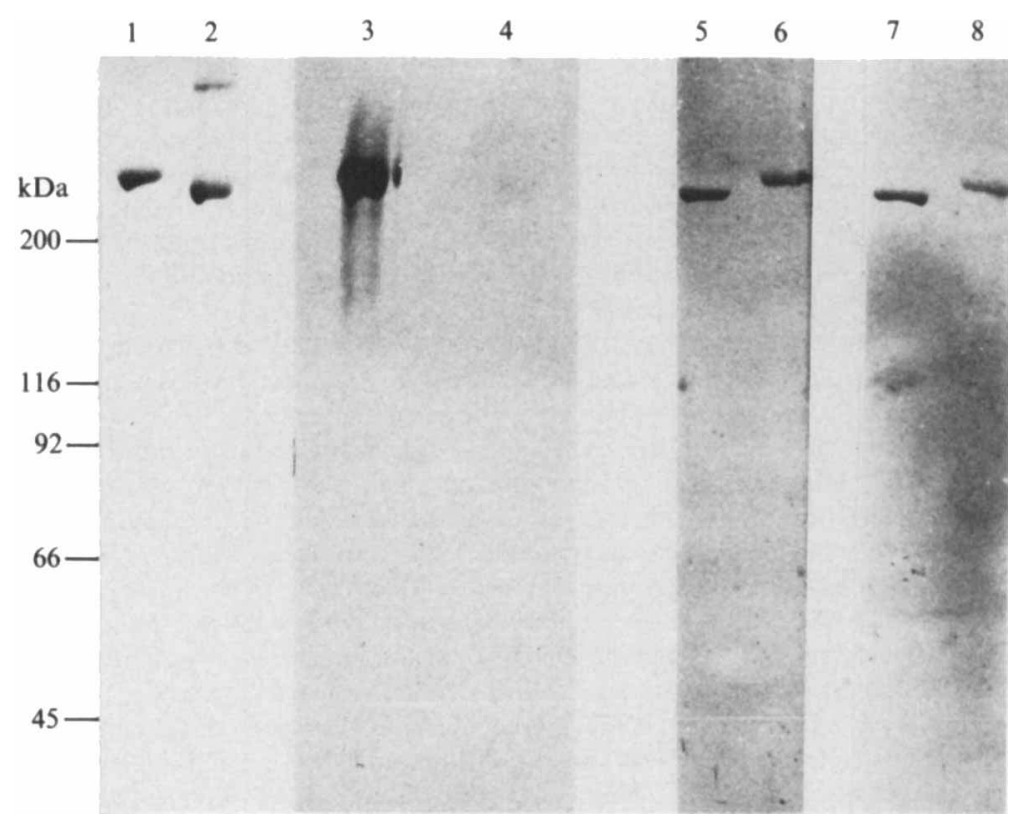

Fig. 1. Reactivity of rabbit toxin $A$ antibody and two mAbs against toxin $A$ and $B$ of $C$. difficile. In all the tests presented, $10 \mu \mathrm{g}$ of toxin was separated on a 5-20\% gradient SDS-PAGE gel and either stained with Coomassie blue (lane 1, toxin A; lane 2, toxin B) or transferred to nitrocellulose for immunoblotting (lanes 3 and 4, toxin $A$ and $B$ developed with the rabbit toxin A antiserum; lanes 6 and 5, toxins $A$ and $B$ developed with $\mathrm{mAb} 1339$; lanes 8 and 7, toxins $A$ and $B$ developed with $\mathrm{mAb} 1134$ ). The additional band at about $500 \mathrm{kDa}$ in lane 2 (toxin $B$ ) is due to incomplete denaturation of the protein during incubation with the SDS-dye solution. It is converted into the $250 \mathrm{kDa}$ band by denaturation for $10 \mathrm{~min}$ at $65^{\circ} \mathrm{C}$.

inserts varied between 2.5 and $7.0 \mathrm{~kb}$. Neither culture supernatants nor total lysates of these clones exhibited cytotoxic activity in the $\mathrm{CHO}$ test. Mixtures of mAbs have been used successfully for identification of clones from a genetic library of mycobacterial DNA (Engers $e t$ $a l ., 1986)$. Screening of the $C$. difficile library with a mixture of four mAbs directed against toxin A did not permit the identification of positive clones. However, it is possible that these mAbs react with only one epitope (v. Eichel-Streiber et al., 1987). Single mAbs not detecting their specific antigen within a genetic library have previously been reported (Young et al., 1985). In the immunoblot analysis of total cell lysates of the recombinant clones, the toxin-A-specific mAb 1337 apparently detected the same protein bands as did the polyclonal rabbit toxin $A$ antiserum (see Fig. 3 and data not shown).

\section{Construction of a restriction map of overlapping clones}

C. difficile DNA has a GC content of $28 \mathrm{~mol} \%$ (Gottschalk et al., 1981). In agreement with this finding, the cloned DNA was preferentially cleaved by restriction nucleases having AT-rich recognition sequences, e.g. BclI, DraI, NdeI, SspI. All cloned segments were cut by RsaI to produce several fragments. A restriction map was established for two representative overlapping clones pCd13 and pCd14 (Fig. 2). Enzymes cutting the inserts more than five times are not included in the map. The $R s a I$ sites in ten different overlapping clones are shown in Fig. 2. Hybridization of the pCd10 insert to RsaI-cleaved plasmid DNA of the 35 positive clones demonstrated that they all contain overlapping DNA segments with a region of about $700 \mathrm{bp}$ common to them all (shaded in Fig. 2). The occurrence of this common region is significant and possibly indicates that a major antigenic determinant is encoded within this region. The absence of antigenic structures in other parts of the holotoxin may explain why the complete toxin gene was not, apparently, isolated (see below). 

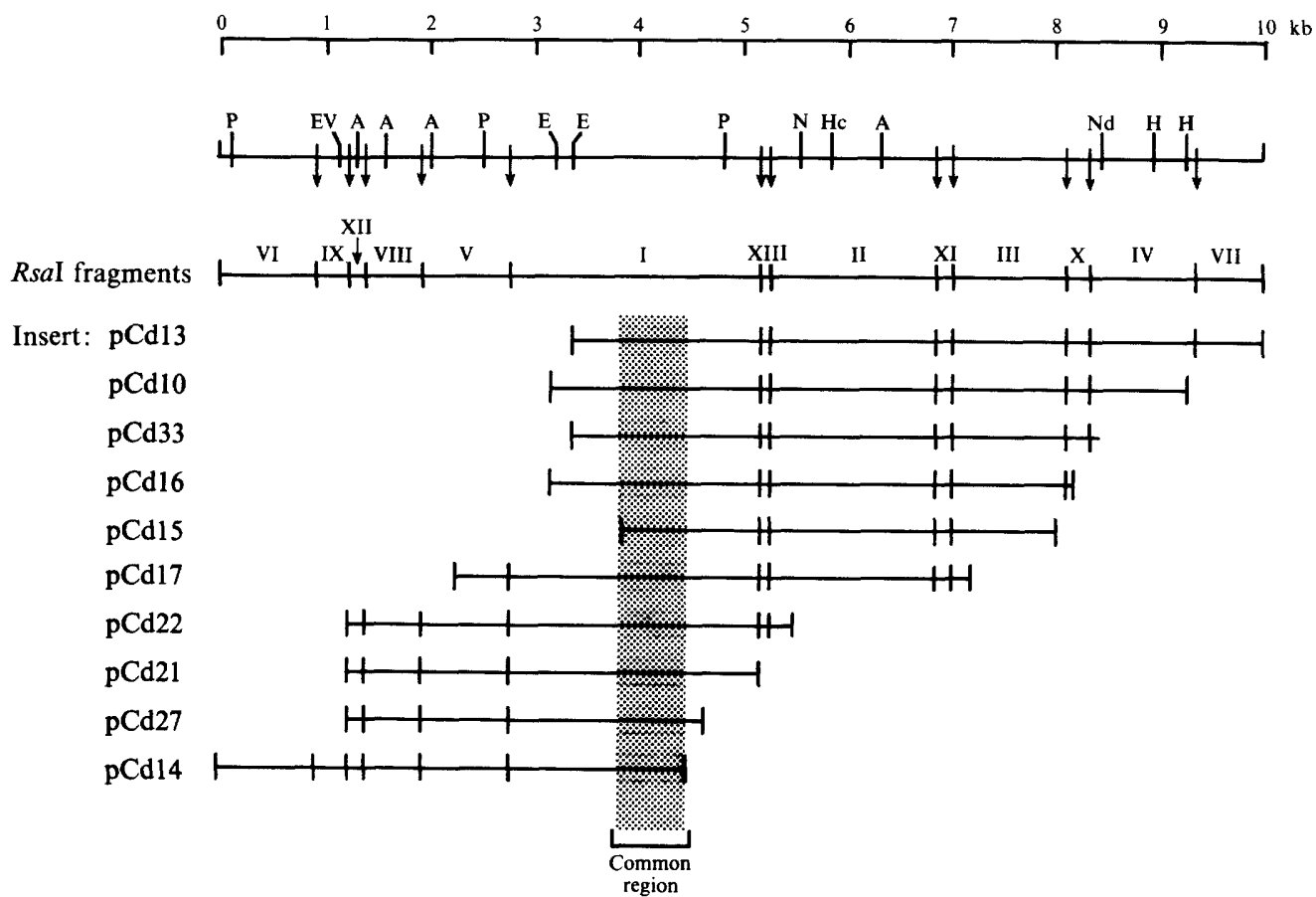

Fig. 2. Physical map of recombinant clones hybridizing in the $10 \mathrm{~kb}$ region. The line immediately below the $\mathrm{kb}$ scale shows a partial restriction map of the $10 \mathrm{~kb}$ region: E, EcoRI; EV, EcoRV; H, HindIII; Hc, HincII; A, AccI; P, PstI; N, NcoI; Nd, NdeI. The following line shows RsaI fragments, numbered I-XIII according to their size. The remainder of the figure shows the inserts in the ten recombinant clones, aligned with the physical map; a $0.7 \mathrm{~kb}$ DNA segment common to all ten clones is shaded. All of the pCd clones shown carried the EcoRI and SacI sites of the pUC12 polylinker on the left side and the BamHI to HindIII sites on the right side of the aligned inserts. The vector pUC12 is omitted to simplify the figure.

Using pCd13 and pCd14 insert DNA as probes, Southern hybridization experiments were done with chromosomal DNA digested with a variety of restriction enzymes. The restriction fragments detected for the individual enzymes were in agreement with those outlined in Fig. 2 (with one exception: PstI, mentioned below), proving that the recombinant DNA originates from one part of the genome. There were seven TaqI sites within the $10 \mathrm{~kb}$ region characterized. Two TaqI fragments had a size of $0.3-0.4 \mathrm{~kb}$; they were part of the RsaI fragments I and IV (Fig. 2 and data not shown). Muldrow et al. (1987) have cloned a $0.3 \mathrm{~kb} \mathrm{TaqI}$ fragment in $\lambda \mathrm{gt} 11$; the expressed protein reacted with toxin A antibodies. This $0.3 \mathrm{~kb}$ fragment hybridized to a $4.5 \mathrm{~kb}$ $P s t \mathrm{I}$ and a $16 \mathrm{~kb}$ HindIII fragment of $C$. difficile chromosomal DNA. Hybridization of pCd14 with $C$. difficile DNA digested with HindIII showed a band of similar size (see Fig. 5, lanes 3 and 4); hybridization to $P$ st I fragments yielded two bands at 4.7 and $9 \mathrm{~kb}$ (data not shown). These results are in agreement with those presented by Muldrow et al. (1987). According to the restriction map in Fig. 2 (first line below the scale) there are two PstI sites with a spacing of $4.7 \mathrm{~kb}$, but there is an additional PstI site between them, so that the $4.7 \mathrm{~kb}$ segment is cut into two fragments of 2.6 and $2.1 \mathrm{~kb}$ by Pst I. Presumably, in C. difficile chromosomal DNA this Pst I site is refractory to digestion, because of base methylation.

\section{Expression of toxin-A-specific polypeptides by the recombinant clones}

To characterize the proteins produced by the recombinant clones, total lysates were analysed by Western blotting (Fig. 3). Initially, only small amounts of protein could be detected with some clones. Therefore the sensitivity of the screening was increased using a sandwich technique including rabbit toxin $\mathrm{A}$ antiserum, goat anti-rabbit serum, and rabbit anti-goat-peroxidase 


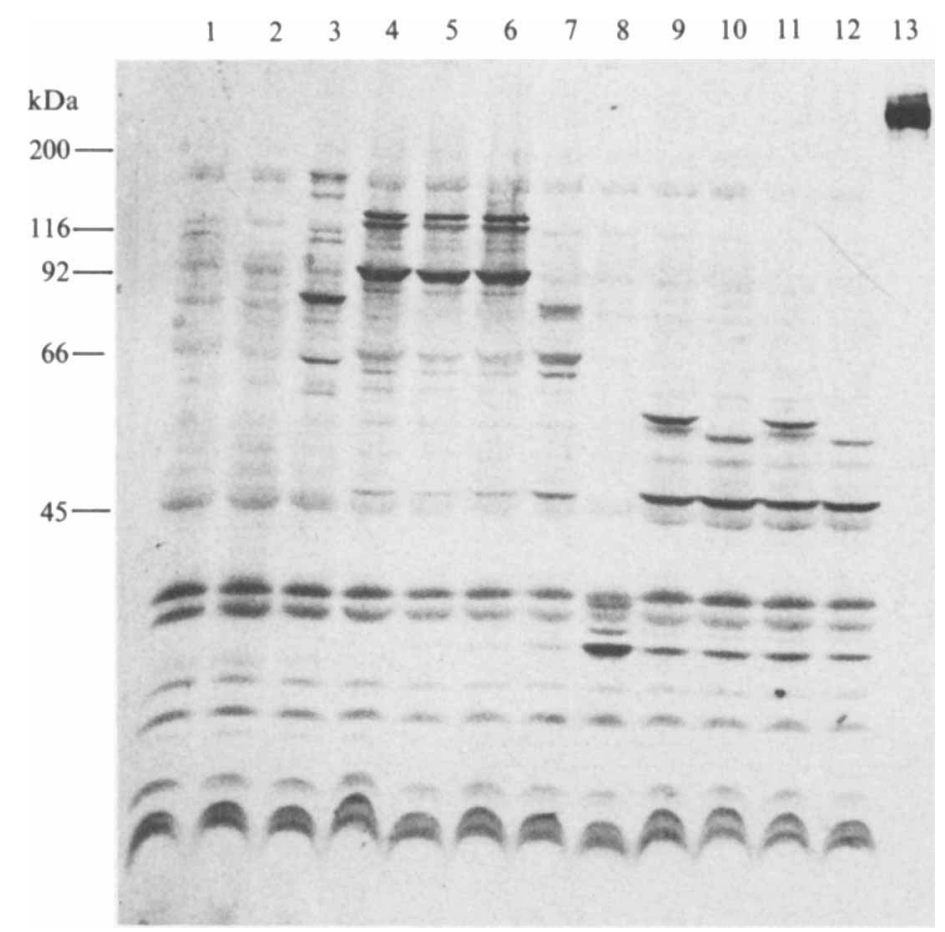

Fig. 3. Immunoblot analysis of recombinant clones expressing toxin A. Samples of toxin A $(10 \mu \mathrm{g})$ and of total lysates of the individual recombinant clones $(50 \mu \mathrm{g})$ were separated on a $5-20 \%$ SDS-PAGE gel and thereafter transferred to nitrocellulose. Proteins were detected using the polyclonal rabbit antiserum specific for toxin A (see Fig. 1). Negative controls: lane 1, E. coli JM83; lane 2, E. coli JM83 transformed with pUC12. Positive control : lane 13, toxin A. Lanes 3-12, E. coli JM83 containing: 3 , pCd14; 4, pCd27; 5, pCd21;6, pCd22; 7, pCd17;8, pCd15; 9, pCd16;10, pCd33; 11, pCd10;12, pCd13 (the protein extracts were submitted to PAGE analysis in the order of the orientation of the recombinant clones within the $10 \mathrm{~kb}$ region: $\mathrm{cf}$. Fig. 2).

conjugate for the detection of proteins on the nitrocellulose. With this procedure proteins could be detected in all 10 clones analysed (Fig. 3). The proteins seen in the two control lanes (Fig. 3, lanes 1 and 2) are stained because of contaminating $E$. coli antibodies which are present in many antisera. The apparent size of the proteins (lanes 3-12) varied between 30 and $170 \mathrm{kDa}$ as determined by PAGE and subsequent immunoblotting. Some of the multiple protein bands seen in Fig. 3 are probably due to premature termination of protein synthesis or protein degradation within the host strain. Similar results have also been obtained using a toxin-A-specific mAb (mAb 1337; data not shown).

Corresponding to a protein equivalent of about $140 \mathrm{kDa}$ (cf. Fig. 3) the overlapping clones studied here apparently contained about $4 \mathrm{~kb}$ of toxin-A-specific DNA sequence. Based on the reported values of the molecular mass of the holotoxin, we therefore estimate to have cloned $1 / 4$ to $1 / 2$ of the toxin A gene. The isolated DNA segment expressing toxin A was smaller than expected from the reported molecular mass of the toxin; this was probably due to a lack of strong antigenic determinants in other parts of the toxin molecule. Alternatively, the small size of the DNA segment isolated might indicate that toxin $A$ is composed of subunits, as has been proposed from a consideration of its reactivity towards one monoclonal antibody (Lyerly et al., $1986 a$ ).

All recombinant clones expressing toxin A sequences contained the $C$. difficile DNA fragments inserted in the same orientation (Fig. 2). This suggests that transcription starts from an external promoter (lac) of the pUC vector. By cloning a $1.9 \mathrm{~kb}$ Pst I fragment from the toxin A gene carried by pCd14, into the PstI site of the polylinker at the $3^{\prime}$ end of the $c r o^{\prime}-l a c Z^{\prime}$ gene on 


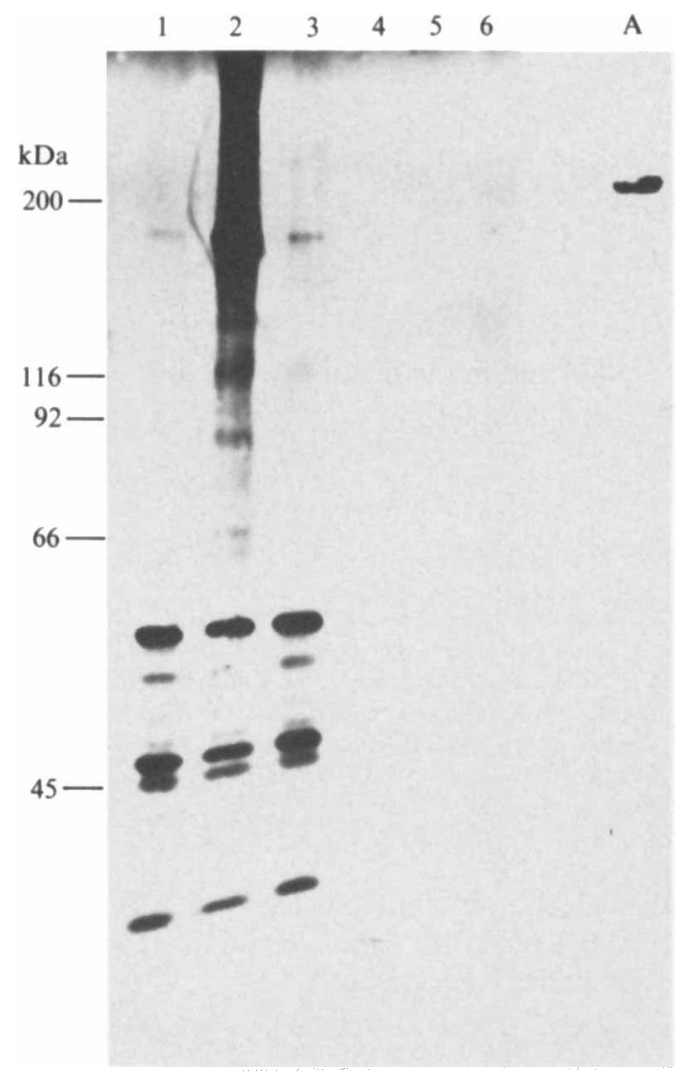

Fig. 4. Western blot analysis of recombinant proteins derived from a $P$ st $I$ fragment subcloned in pEX1, 2 and 3 . A Pst I fragment from $2.6 \mathrm{~kb}$ to the right side of the common region was isolated from pCd14 and cloned into pEX1, 2 and 3 (see Fig. 2). Recombinant protein was isolated after induction (at $42^{\circ} \mathrm{C}$ ) of the recombinant $E$. coli strains harbouring the following plasmids: lanes 1-3, Pst I fragment in the correct orientation (lane 1, pEX1; lane 2, pEX2; lane 3, pEX3); lanes 4-6, PstI fragment in the opposite (-) orientation (lane 4, pEX1; lane 5, pEX2; lane 6, pEX3). Lane A contains pure toxin A. Ten $\mu \mathrm{g}$ of toxin $\mathrm{A}$ and equal volumes $(25 \mu \mathrm{l})$ of total lysates of the recombinant clones grown under identical conditions (see Methods) were separated on a 5-20\% SDS-PAGE gel and thereafter transferred to nitrocellulose. The blot was stained with the toxin-A-specific mAb 1337.

pEX2, a hybrid gene was created, which encoded large amounts of a fusion protein of $170 \mathrm{kDa}$ (Fig. 4). This is approximately the right size for a construction in which the $c r o^{\prime}-l a c Z^{\prime}$ and the toxin-A-coding sequences are in frame. Trace amounts of the $170 \mathrm{kDa}$ protein were also detected with the pEX1 and pEX3 derivatives, suggesting that during overexpression, translational frame shifting can occur as described by Stanley (1983). In addition, at least three minor proteins $(29,46$ and $52 \mathrm{kDa})$ that reacted with the mAb1337 raised against toxin A were detected in $\mathrm{pEX} 2$. These proteins were also produced when the PstI fragment was cloned into $\mathrm{pEX} 1$ or $\mathrm{pEX} 3$, in which the toxin A sequences are in different reading frames, indicating that the AT richness $(72 \%)$ of the cloned $C$. difficile DNA induced reinitiation of translation, giving rise to these toxin A reactive proteins in $\mathrm{pEX} 1,2$ and 3 . When the Pst I fragment was inserted in the opposite orientation no recombinant proteins were produced, thus confirming the direction of transcription of the toxin A gene as being from left to right as shown in Fig. 2.

We calculated that the toxin-A-encoding DNA sequences as deduced from the largest protein detectable with the polyclonal antiserum in the Western blot (Fig. 3) extended from RsaI fragment XII to I. According to this reasoning the coding sequence of all of the positive clones ends near the Pst I site of RsaI fragment I, suggesting that the $3^{\prime}$ end of the gene should be within this region. Deletion of sequences downstream of the Pst $\mathrm{I}$ site (at $4.8 \mathrm{~kb}$ ) from $\mathrm{pCd} 22$, pCd17, 


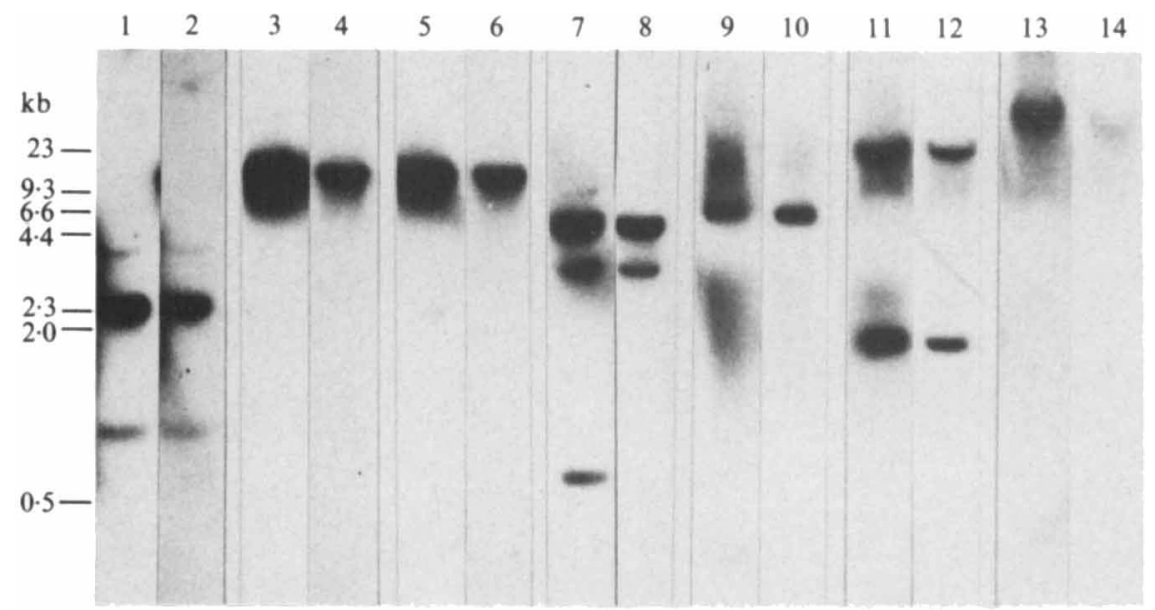

Fig. 5. Southern hybridization of radioactively labelled pCd14 insert DNA to digests of $C$. difficile chromosomal DNA at two different stringencies. Even-numbered lanes, $T_{\mathrm{m}}-15^{\circ} \mathrm{C}$; odd-numbered lanes, reprobing of the identical nitrocellulose sheet at $T_{\mathrm{m}}-35^{\circ} \mathrm{C}$. Lanes 1 and $2, R s a \mathrm{I}$; lanes 3 and 4, HindIII; lanes S and 6, HincII; lanes 7 and 8, AccI; lanes 9 and 10,EcoRI; lanes 11 and 12, EcoRV; lanes 13 and 14, SacI. Minor differences in the labelled DNA fragments (lanes 7 and 8) are due to photographic reproduction.

pCd10 and pCd13 greatly reduced the abundance of the respective toxin-A-related proteins (data not shown), thereby suggesting that this region corresponds to a domain conferring stability and/or protease resistance upon toxin A.

\section{Search for toxin-A-related genomic DNA}

The clones $\mathrm{pCd} 13$ and $\mathrm{pCd} 14$, covering the entire $10 \mathrm{~kb}$ region, were used in hybridization experiments to screen for toxin-A-related sequences in the $C$. difficile genome. Insert DNA was hybridized to $C$. difficile chromosomal DNA digested with $R s a \mathrm{I}, H i n \mathrm{IIII}, H i n c I I, A c c \mathrm{I}, E c o$ RI, $E c o R V$, and $S a c I$, respectively. In these experiments variation of the stringency from $T_{\mathrm{m}}-13^{\circ} \mathrm{C}$ to $T_{\mathrm{m}}-47^{\circ} \mathrm{C}$ during hybridization did not lead to changes in the pattern of bands detected. A typical experiment, using pCd14 as a probe at $35^{\circ} \mathrm{C}$ and $15^{\circ} \mathrm{C}$ below $T_{\mathrm{m}}$, is shown in Fig. 5. The $0.7 \mathrm{~kb} \mathrm{AccI}$ fragment shown in lane 7 was also seen in lane 8 on the original autoradiogram. The results indicate that additional sequences related to toxin $A$ are not present in the $C$. difficile genome. The hybridization experiments indicate either that the toxins do not have any similarity, which would be surprising considering the cross-reactivity of the monoclonal antibodies, or that both toxins are encoded by a single gene. At present we cannot distinguish between these two possibilities. The search for a separate potential toxin B gene would require the preparation of a high-titre toxin $B$ antiserum. At the present time such an antiserum is difficult to obtain due to the low immunogenicity and additional immunosuppressive effects of this potent toxin.

We gratefully acknowledge Dr T. Chakraborty and Dr R. E. Streeck for critical revision of the manuscript, and Mrs Junker and Mrs Salomon for typing the paper. The data presented herein contain parts of the doctoral thesis of M.W. This work was supported by grants from the Deutsche Forschungsgemeinschaft.

\section{REFERENCES}

Banno, Y., Kobayashi, T. \& Kono, K. (1984). Biochemical characterization and biological actions of two toxins (D-1 and D-2) from Clostridium difficile. Review of Infectious Diseases 6, 11-20.
Bartlett, J. G., Chang, T. W. \& GurwitT, M. (1978). Antibiotic associated pseudomembranous colitis due to toxin producing clostridia. New England Journal of Medicine 298, 531-534. 
Chang, T. W., Sullivan, N. M. \& Wilkins, T. D. (1986). Insusceptibility of fetal intestinal mucosa and fetal cells to Clostridium difficile toxins. Acta pharmacologica sinica 7, 448-453.

Eichel-STreiber, C.v., HaRperath, U., Bosse, D. \& Hadding, U. (1987). Purification of two high molecular weight toxins of Clostridium difficile which are antigenetically related. Microbial Pathogenesis 2, 307-318.

Eisel, U., Jarausch, W., Goretzki, K., Henschen, A., Engels, J., Weller, U., Hudel, M., HaberMaNN, E. \& NiemanN, H. (1986). Tetanus toxin: primary structure, expression in $E$. coli and homology with botulinum toxins. EMBO Journal 5, 24952502.

Engers, H. D., Houba, V., Bennedsen, J., Buchanan, T. M., Chaparas, S. D., Kadival, G., Closs, O., David, J. R., van Embden, J. D. A., Godal, T., Mustafa, S. A., Ivanyi, J., Young, D. B., Kaufmann, S. H. E., KhomenKo, A. G., Kolk, A. H. J., Kubin, M., Louis, J. A., Minden, P., Shinnick, T. M., Trnka, L. \& Young, R. A. (1986). Results of a World Health Organizationsponsored workshop to characterize antigens recognized by mycobacterium-specific monoclonal antibodies. Infection and Immunity 51, 718-720.

Fairweather, N. F., Lyness, V. A., Pickard, D. J., Allen, G. \& Thomson, R. O. (1986). Cloning, nucleotide sequencing, and expression of tetanus toxin fragment $\mathrm{C}$ in Escherichia coli. Journal of Bacteriology 165, 21-27.

GeORGE, R. H. (1986). The carrier state: Clostridium difficile. Journal of Antimicrobial Chemotherapy 18 (Suppl. A), 47-58.

GotTschalk, G., Andreesen, J. R. \& HipPe, H. (1981). The genus Clostridium. In The Prokaryotes, a Handbook on the Habitats, Isolation and Identification of Bacteria, pp. 1767-1803. Edited by M. P. Starr, H. Stolp, H. G. Trüper, A. Balows \& H. G. Schlegel. Berlin: Springer.

Hanahan, D. (1983). Studies on transformation of Escherichia coli with plasmids. Journal of Molecular Biology 166, 557-580.

Haymerle, J., Herz, G. B., Frank, R. \& Stanley, K. K. (1986). Efficient construction of cDNA libraries in plasmid expression vectors using an adaptor strategy. Nucleic Acids Research 14, 86158624.

Howley, P. M., IsRael, M. A., LAW, M. F. \& Martin, M. A. (1979). A rapid method for detecting and mapping homology between heterologous DNAs. Journal of Biological Chemistry 254, 48764883.

LAEMMLI, U. K. (1970). Cleavage of structural proteins during the assembly of the head of bacteriophage $\mathrm{T} 4$. Nature, London 227, 680-685.

Laughon, B. E., Viscidi, R. P., Gdovin, S. L., Yolken, R. H. \& Bartlett, J. G. (1984). Enzyme immunoassays for detection of Clostridium difficile toxins $\mathbf{A}$ and $\mathbf{B}$ in fecal specimens. Journal of Infectious Diseases 149, 781-788.

LibBY, J. M. \& Wilkins, T. D. (1982). Production of antitoxins to two toxins of Clostridium difficile and immunological comparison of the toxins by crossneutralisation studies. Infection and Immunity 35, 374-376.
Lyerly, D. M., Saum, K. E., MacDonald, D. K. \& WilkINS, T. D. (1985a). Effects of Clostridium difficile toxins given intragastrically to animals. Infection and Immunity 47, 349-352.

Lyerly, D. M., Phelps, C. J. \& Wilkins, T. D. $(1985 b)$. Monoclonal and specific polyclonal antibodies for immunoassay of Clostridium difficile toxin A. Journal of Clinical Microbiology 21, 12-14.

Lyerly, D. M., Phelps, C. J., Toth, J. \& Wilkins, T. D. $(1986 a)$. Characterization of toxins A and B of Clostridium difficile with monoclonal antibodies. Infection and Immunity 54, 70-76.

Lyerly, D. M., Roberts, M. D., Phelps, C. J. \& Wilkins, T. D. (1986 b). Purification and properties of toxins $\mathrm{A}$ and $\mathrm{B}$ of Clostridium difficile. FEMS Microbiology Letters 33, 31-35.

Maniatis, T., Fritsch, E. F. \& Sambrook, J. (1982). Molecular Cloning: a Laboratory Manual. Cold Spring Harbor, NY: Cold Spring Harbor Laboratory.

MEssing, J. (1979). A multipurpose cloning system based on the single-stranded DNA bacteriophage M13. In Recombinant DNA Technical Bulletin, part 2, pp. 43-48. NIH Publication no. 79-99.

MiddlebrooK, J. L. \& Dorland, R. B. (1984). Bacterial toxins: cellular mechanisms of action. Microbiological Reviews 48, 199-221.

MiURA, K. I. (1967). Preparation of bacterial DNA by phenol-pH9-RNase method. Methods in Enzymology 12, 543-545.

Muldrow, L. L., Ibeanu, G. C., Lee, N. I., Bose, N. K. \& Johnson, J. (1987). Molecular cloning of Clostridium difficile toxin A gene fragment in $\lambda \mathrm{gt} 11$. FEBS Letters 213, 249-253.

Pothoulakis, C., Barone, L. M., Ely, R., Faris, B., Clark, M. E., Franzblau, C. \& lamont, J. T. (1986). Purification and properties of Clostridium difficile cytotoxin B. FEMS Microbiology Letters 33, 31-35.

REED, K. C. \& MANN, D. A. (1985). Rapid transfer of DNA from agarose gels to nylon membranes. Nucleic Acids Research 13, 7207-7221.

Rigby, P. W. J., Diekman, M., Rhodes, C. \& Berg, P. (1977). Labeling deoxyribonucleic acid to high specific activity in vitro by nick translation with DNA polymerase. Journal of Molecular Biology 113, 237-251.

RIHN, B., SCHEFTEL, J. M. \& GIRARDOT, R. (1984). A new purification procedure for Clostridium difficile enterotoxin. Biochemical and Biophysical Research Communications 124, 690-695.

SOUTHERN, E. M. (1975). Detection of specific sequences among DNA fragments separated by gel electrophoresis. Journal of Molecular Biology 98, 503-517.

STANLEY, K. K. (1983). Solubilization and immunedetection of $\beta$-galactosidase hybrid proteins carrying foreign antigenic determinants. Nucleic Acids $R e$ search 11, 4077-4092.

Stanley, K. K. \& Luzio, J. P. (1984). Construction of a new family of high efficiency bacterial expression vectors: identification of cDNA clones coding for human liver proteins. EMBO Journal 3, 1429-1434.

Sullivan, N. M., Pellett, S. \& Wilkins, T. D. (1982). Purification and characterization of toxins A and B of Clostridium difficile. Infection and Immunity 35, 1032-1040. 
Timmis, K. N., Montenegro, M. A., Bulling, E., ChaKRabORTY, T. \& SANYAL, S. (1984). Genetics of Toxin Synthesis in Pathogenic Gram-negative Enteric Bacteria, pp. 13-27. London: Academic Press.

VolKAERT, G. (1987). A systematic approach to chemical DNA sequencing by subcloning into pGV451 and derived vectors. Methods in Enzymology 155, 231-251.

Yanisch-PerRon, C., Vieira, J. \& Messing, J. (1985).
Improved M13 phage cloning vectors and host strains: nucleotide sequences of the M13mpl8 and pUC19 vectors. Gene 33, 103-119.

Young, R. A., Bloom, B. R., Grosskinsky, C. M., Ivanyi, J., Thomas, D. \& Davis, R. W. (1985). Dissection of Mycobacterium tuberculosis antigens using recombinant DNA. Proceedings of the National Academy of Sciences of the United States of America 82, 2583-2587. 